\title{
NIH scientists chafe under ethics rules on industry ties
}

Washington. You are a scientist from the US National Institutes of Health (NIH) on a visit to a company. Someone calls a lunch break and offers you a tuna-fish sandwich. What do you say? "Thanks, but I'm not hungry."

That, at least, is what NIH scientists are now being taught in a training video-tape. The tape, along with almost weekly memoranda on other issues involving contacts with outsiders, has become part of a body of ethics rules and regulations that threaten to turn the agency, once renowned for its re-

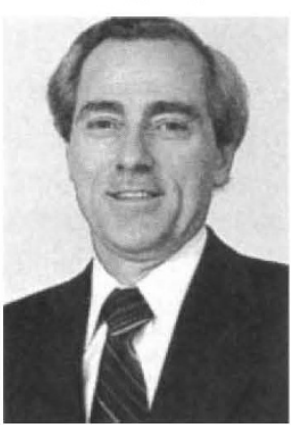

French Anderson paid the price for blazing trail to industry. search freedom and hassle-free science, into one of the most restrictive in the government.

The culprit is the 1986 Technology Transfer Act, which encourages US agencies to collaborate with industry to commercialize government inven-

tions. One of the mechanisms for this is a Cooperative Research and Development Agreement (CRADA), in which government and industry scientists work together with the ultimate aim of generating a marketable product. NIH now have about 160 CRADAs, more than any other agency, and it is that success that worries NIH administrators.

The problem is that collaboration means frequent visits between NIH scientists and industry, each one of which, from an ethics officer's point of view, offers an opportunity for undue influence and profiteering. Scientists who consult and give speeches outside their usual NIH duties, as more than $440 \mathrm{NIH}$ researchers did in 1990 , are also seen to be skating on thin ethical ice.

With congressional investigators ever vigilant, and science itself under unprecedented scrutiny, NIH officials have become increasingly sensitive to even the appearance of conflict. The result is some of the most intrusive guidelines in the government. Starting from government-wide regulations issued by the US Office of Government Ethics in 1989, NIH officials have tried to respond to each new ethical dilemma raised by the agency's expanding industry connections.

The evolving rules and guidelines range from the cumbersome to the absurd. One memorandum cites the example of an NIH scientist who had been given approval to give a speech as an 'outside activity' something that is not strictly a part of his official capacities. But the researcher made the mistake of discussing his published work at length. According to the memorandum, he should not have talked about his own work for more than three minutes of every hour. Any more, NIH decreed, smacks of using his "public office for private gain".

Another memorandum tackles an apparently trivial aspect of privately subsidized travel: the free shaving kit that some airlines offer. If it is worth more than $\$ 5$, the kit might qualify as an inappropriate gift. Better not to accept it, NIH ethics officers warned.

The entire issue of travel is sensitive since Congress slashed the travel budget of NIH's parent agency in retribution for sending what some legislators thought were too many researchers to last year's International AIDS Meeting in Florence, Italy. Now, with little money to travel on their own, NIH scientists must often wait months to gain approval to accept airfare for outside activities, and requests for paid consulting must go all the way to the NIH director.

"For all practical purposes, it's a moot point", says Jeffrey Schlom, chief of the Laboratory of Tumor Immunology and $\mathrm{Bi}$ ology and Experimental Oncology at NIH's National Cancer Institute. "If a company called here tomorrow to ask me to visit them, I couldn't go. There's zero money in our travel budget and it takes months to get approval."

As the first NIH scientist to become involved in a CRADA, W. French Anderson can offer more than the usual number of horror stories. A pioneer in genetic therapy, Anderson has several CRADAs with Genetic Therapy Inc. (GTI). To protect himself from what he assumes are the inevitable questions, Anderson has chosen to rearrange his life. His salary payments are sent directly to his lawyer, who controls his bank account and his investments. He says he has spent about $\$ 50,000$ of his own money on legal advice, and at one point had three personal lawyers. He owns no stock in any company.

When GTI went public, Anderson worried whether his discussions with friends about his work might violate the insidertrading prohibitions of the US Securities and Exchange Commission. At the same time, Anderson became concerned that a federal rule that prohibits a company from advertising its connections with government researchers might clash with another rule that a company must identify its affiliation with outside scientists. And earlier this month, when Anderson announced that he might be leaving NIH and taking an academic position to follow his wife to the West
Coast, he found that he was prohibited from even discussing the future of his collaboration with GTI. Only a waiver last week from the NIH director, Bernadine Healy, allowed him to begin planning how to keep the collaboration alive.

Even after the lawyers had worked out the ground rules of the collaboration with GTI to avoid any possible perception of conflict of interest, Anderson thought of something that they had missed. Every Tuesday, when he visits the nearby company, tradition has it that he gets a chocolate doughnut. Would this be the improper 'gift' that finally brought in the investigators? Better safe than sorry, he decided, giving the company $\$ 50$ to establish a doughnut fund for him. "To live your life on the advice of a battery of attorneys is no fun," he says.

Patricia Werner, NIH ethics coordinator, explains that the rules are designed with the researchers in mind: "The whole idea is not to keep scientists from doing what they want to do, but to protect them" should they be investigated, she says. But many NIH researchers would rather accept the risks. "These rules seem totally illogical and repressive", says Schlom. "I don't think the ethics people realize what the procedures have done to day-to-day life at NIH."

"It's just a very cumbersome process," agrees Philip Chen, NIH associate director for intramural affairs. He believes, along with many of his colleagues, that NIH has overreacted to the federal guidelines. But he cannot see how to ease restrictions without inviting in crusading investigators. "We're in the early stages of developing a technology transfer process", he explains. "I admit that there's an awful lot of red tape, but I don't see any good way to reduce it at this moment."

The situation may improve next month when the Office of Government Ethics is expected to release its new standards for ethical conduct. A proposed version, issued for public comment last July, sought to clarify many of the issues with which NIH's own ethics officers have been wrestling.

Some of the changes are obvious improvements (the shaving kit, for example, would be acceptable). Others, including a controversial section that would prohibit government researchers from working for their professional societies on government time, have been delayed for further consideration. Although the final language is not yet public, the rules are expected to make unnecessary some of the most extreme agency regulations. But, given the current climate of fear at NIH, few researchers expect a return to a time when they were free to concentrate on science.

Christopher Anderson 